\title{
PENGARUH VARIASI BIOMASSA Pistia stratiotes L. TERHADAP PENURUNAN KADAR BOD, COD, DAN TSS LIMBAH CAIR TAHU DI DUSUN KLERO SLEMAN YOGYAKARTA
}

\author{
M. Fachrurozi, Listiatie Budi Utami, Dyah Suryani \\ Fakultas Kesehatan Masyarakat Universitas Ahmad Dahlan, Yogyakarta
}

\begin{abstract}
Background: Some industries know in Orchard of direct Klero Sleman Yogyakarta throw away the liquid waste to river Gawe without done a processing beforehand, so that cause the river water becomes the impure. Others, there are sigh from society of around industry know that is incidence of smelling, so that society which live in about industry know to become annoyed. This Research aim to know influence of variation of biomassa Pistia stratiotes L. to degradation rate of BOD, COD, and TSS liquid waste know at Orchard of Klero Sleman Yogyakarta. Processing of liquid waste by exploiting Pistia stratiotes $L$. expected can lessen compound rate of impure toxic compound and also consisting is in underwater of waste.

Method: this was pure experimental research using complete random device. Involved in variable was variation of biomassa Pistia stratiotes L. as independent variable. Rate of Biologycal Oxygen Demand (BOD), Chemical Oxygen Demand (COD), and Total Suspended Solid (TSS) as dependent variable. Research executed in Countryside of Pereng Sumberharjo Yogyakarta. Measurement of parameter BOD, COD, and TSS conducted in Laboratory Hall Technique Health of Environment (BTKL) Bantul. Sample for this research was liquid waste know in Orchard of Klero Sleman Yogyakarta. Result of research analyzed to use test of ANOVA and test of BNT (Least Significant Different).

Result: Result of analysis influence variation of biomassa Pistia stratiotes L. to degradation of rate BOD, COD, and TSS use test of ANOVA show value equal to 2966,67, 8836,57, 1337,33 with level of significance equal to $0,000(p<0,05)$ which indication that variation excelsior of biomassa Pistia stratiotes $\mathrm{L}$. hence excelsior also degradation of rate of BOD, COD, and TSS.

Conclusion: There was influences which significant between variation of biomassa Pistia stratiotes $\mathrm{L}$. to degradation of rate of BOD, COD, and TSS liquid waste know in Orchard of Klero Sleman Yogyakarta.
\end{abstract}

Keywords: Biomassa, Pistia Stratiotes L., BOD, COD, and TSS Liquid Wast, Soybean cake

\section{PENDAHULUAN}

Industri tahu merupakan usaha yang didirikan dalam rangka pengembangan kegiatan dibidang pangan yang mempunyai dampak positif dan negatif bagi lingkungan. Dampak positif berupa pemenuhan kebutuhan masyarakat akan sumber pangan sedangkan dampak negatif dari industri tahu berupa limbah buangan yang menimbulkan masalah pencemaran sehingga merusak lingkungan. Pencemaran lingkungan tersebut berupa hasil pembuangan limbah padat (ampas tahu) dan limbah cair ${ }^{1}$. Sebagian besar limbah cair yang dihasilkan oleh industri pembuatan tahu adalah cairan kental yang terpisah dari gumpalan tahu yang disebut air dadih. Cairan ini mengandung kadar protein yang tinggi dan dapat segera terurai. Limbah cair ini sering dibuang secara langsung tanpa pengolahan terlebih dahulu sehingga menghasilkan bau busuk dan mencemari sungai. Sumber limbah cair lainnya berasal dari pencucian kedelai, pencucian peralatan proses, pencucian lantai dan pemasakan serta larutan bekas rendaman kedelai. Jumlah limbah cair yang dihasilkan oleh industri pembuat tahu kira-kira 15-20 l/kg bahan baku kedelai, sedangkan bahan pencemarnya kira-kira untuk TSS sebesar $30 \mathrm{~g} / \mathrm{kg}$ bahan baku kedelai, BOD $65 \mathrm{~g} / \mathrm{kg}$ bahan baku kedelai dan 
COD $130 \mathrm{~g} / \mathrm{kg}$ bahan baku kedelai ${ }^{2}$. Beberapa industri tahu di Dusun Klero Sleman Yogyakarta langsung membuang limbah cair ke sungai Gawe tanpa dilakukan pengolahan terlebih dahulu, sehingga menyebabkan air sungai menjadi keruh dan tercemar. Selain itu, terdapat keluhan dari masyarakat di sekitar industri tahu yaitu timbulnya bau tidak sedap, sehingga masyarakat yang tinggal di sekitar industri tahu menjadi terganggu.

Pada umumnya air lingkungan yang telah tercemar kandungan oksigennya sangat rendah. Hal itu karena oksigen yang terlarut di dalam air diserap oleh mikroorganisme untuk memecah atau mendegradasi bahan buangan organik sehingga menjadi bahan yang mudah menguap (yang ditandai dengan bau busuk). Selain itu, bahan buangan organik juga dapat bereaksi dengan oksigen yang terlarut di dalam air mengikuti reaksi oksidasi biasa. Makin banyak bahan buangan organik yang ada di dalam air, makin sedikit sisa kandungan oksigen yang terlarut di dalamnya. Dengan melihat kandungan oksigen yang terlarut di dalam air dapat ditentukan seberapa jauh tingkat pencemaran air lingkungan telah terjadi ${ }^{3}$. Salah satu pengolahan limbah yang cukup murah dan aman adalah pengolahan secara biologi dengan memanfaatkan tanaman tertentu sebagai biofilter, karena tanaman mempunyai kemampuan untuk mengikat unsur-unsur dari lingkungan sekitarnya dan sensitif terhadap semua perubahan habitat lingkungan baik fisik maupun kimia ${ }^{4}$. Tanaman kayu apu (Pistia stratiotes L.) merupakan tanaman air yang biasanya dianggap gulma oleh masyarakat. Namun, tumbuhan tersebut dapat memberikan keuntungan bagi perairan yang tercemar. Tanaman kayu apu merupakan jenis gulma air yang sangat cepat tumbuh dan mempunyai daya adaptasi terhadap lingkungan baru. Tanaman pengganggu ini dapat digunakan untuk menyerap unsur-unsur toksis pada air limbah. Pada umumnya, tumbuhan akan menyerap unsur-unsur hara yang larut dalam air melalui akarakarnya ${ }^{5}$.

Pencemaran lingkungan adalah masuknya atau dimasukkannya makhluk hidup, zat, energi, dan atau komponen lain ke dalam lingkungan atau berubahnya tatanan lingkungan oleh kegiatan manusia atau proses alam, sehingga kualitas lingkungan turun sampai ke tingkat tertentu yang menyebabkan lingkungan menjadi kurang atau tidak dapat berfungsi lagi sesuai dengan peruntukkannya ${ }^{6}$. Pencemaran air adalah masuknya atau dimasukkannya makhluk hidup, zat, energi dan atau komponen lain ke dalam air oleh kegiatan manusia, sehingga kualitas air turun sampai ketingkat tertentu yang membahayakan, yang mengakibatkan air tidak berfungsi lagi sesuai dengan peruntukkannya ${ }^{7}$. Sebagian besar buangan industri tahu adalah limbah cair, yaitu berupa sisa susu tahu yang tidak menggumpal menjadi tahu. Oleh karena itu, buangan tahu masih mengandung zat-zat organik, seperti protein, karbohidrat, lemak. Disamping mengandung zat terlarut juga mengandung padatan terendap, seperti potongan tahu yang hancur dalam pemrosesan karena kurang sempurna saat penggumpalannya ${ }^{8}$. Air limbah tahu adalah air buangan yang merupakan air limbah yang sudah tidak dapat dipergunakan oleh masyarakat dan mempunyai efek yang sangat membahayakan kesehatan manusia, merugikan ekonomi, merusak atau membunuh kehidupan dalam air dan dapat merusak keindahan. Pada umumnya industri tahu menggunakan air untuk proses maupun untuk pencucian alat dan kedelai, sebagian besar air yang telah dipergunakan dibuang ke lingkungan. Disamping dalam bentuk cair, limbah tahu juga keluar dalam bentuk padat ${ }^{9}$.

BOD (Biological Oxygen Demand) adalah jumlah oksigen yang diperlukan oleh bakteri untuk menguraikan hampir semua zat organik terlarut dan tersuspensi dalam keadaan aerobik ${ }^{4}$. Uji BOD digunakan secara luas untuk menentukan kekuatan pencemaran dari limbah domestik dan limbah industri, dalam arti oksigen yang akan dibutuhkan bila limbah tersebut dibuang ke air lingkungan dalam kondisi aerobik. Uji ini merupakan salah satu uji terpenting dalam pengawasan aktivitas pencemaran sungai. Dengan menggunakan uji ini memungkinkan untuk menentukan tingkat pencemaran air 
lingkungan setiap waktu ${ }^{3}$. Nilai BOD ini juga dipakai untuk mengukur kemelimpahan limbah organik dalam upaya perencanaan perlakuan biologis dan evaluasi efisiensi sistem perlakuan penanggulangan limbah organik. Perubahan kandungan bahan organik ini yang dinyatakan dengan nilai BOD akan terjadi pada setiap proses pembersihan sendiri pada sungai yang tercemar oleh limbah organik ${ }^{10}$.

COD (Chemical Oxygen Demand) adalah jumlah oksigen yang dibutuhkan untuk mengoksidasi bahan buangan yang ada dalam air dapat teroksidasi melalui reaksi kimia ${ }^{3}$. Pengukuran $C O D$ ini diperlukan untuk mengukur kebutuhan oksigen terhadap zat organik yang sukar dihancurkan secara oksidasi. Oleh karena itu dibutuhkan bantuan pereaksi oksidator yang kuat dalam suasana asam yaitu kalium bikromat ${ }^{11}$.

TSS (Total Suspended Solid) merupakan bahan-bahan tersuspensi dan tidak larüt dalam air. Padatan tersuspensi terdiri dari partikel-partikel yang ukuran maupun beratnya lebih kecil daripada sediment. Misalnya bahan-bahan organik tertentu, sel-sel mikro, tanah liat dan lain-lain. Padatan tersuspensi ini dalam air berasal dari proses settling (turun sendiri karena gaya tarik bumi) dari zat melayang dalam air. Padatan tersuspensi akan mengurangi penetrasi cahaya atau sinar ke dalam air sehingga mempengaruhi oksigen dan fotosintesis ${ }^{12}$ Padatan tersuspensi di dalam air limbah industri dapat berasal dari adanya kegiatan-kegiatan pencucian dan lepasnya bahanbahan baku industri. Tinggi rendahnya nilai TSS akan berpengaruh terhadap mutu badan air penerima limbah. Adanya bahan padat di air menyebabkan kualitas air tidak baik, menimbulkan berbagai reaksi, dan mengganggu estetika. Setelah beberapa waktu padatan tersuspensi akan mengendap ${ }^{13}$.

Kayu apu (Pistia stratiotes L.) sebagai tumbuhan air memiliki potensi dalam menurunkan kadar pencemar air limbah yang memiliki kadar organik tinggi ${ }^{14}$.Kayu apu juga dibudidayakan sebagai makanan ternak. Tanaman ini dipercaya mempunyai khasiat sebagai pelembut dan penyejuk, obat disentri, haematurie, antiseptik, insektisida dan obat asma. Kemampuan mencengkeram Lumpur dengan berkasberkas akarnya kadang dimanfaatkan sebagai pembersih air sungai yang sangat kotor. Dalam industri tanaman ini digunakan sebagai penyerap unsur-unsur toksis pada air limbah ${ }^{15}$. Tanaman kayu apu (Pistia stratiotes L.) mempunyai keunggulan seperti daya berkecambah yang tinggi, pertumbuhan cepat, tingkat absorbsi atau penyerapan unsur hara dan air yang besar, mudah ditemukan, dan daya adaptasi yang tinggi terhadap iklim ${ }^{16 .}$

Fenomena yang terjadi tersebut sangat menarik untuk diteliti dan diketahui lebih dalam. Sehingga penulis mencoba untuk melakukan penelitian yang berkaitan dengan hal tersebut. Latar belakang tersebut akhirnya mendorong penulis untuk melakukan penelitian dengan judul "Pengaruh Variasi Biomassa Pistia stratiotes L. Terhadap Penurunan Kadar BOD, COD, dan TSS Limbah Cair Tahu Di Dusun Klero Sleman Yogyakarta".

\section{METODE PENELITIAN}

Jenis penelitian ini adalah penelitian eksperimental murni (true experiment) yang menggunakan Rancangan Acak Lengkap (RAL). Peneliti melakukan intervensi terhadap tanaman Pistia stratiotes L. yang dimasukkan ke dalam bejana yang berisi air limbah dengan konsentrasi yang didapat pada uji pendahuluan. Penelitian ini menggunakan 3 kali pengulangan/ replikasi. Lokasi penelitian dilaksanakan di Desa Pereng, Sumberharjo, Prambanan Yogyakarta. Sedangkan pengukuran parameter dilakukan di laboratorium Balai Teknik Kesehatan Lingkungan di Banguntapan Bantul. Analisis data dilakukan melalui 2 tahap yaitu Uji ANAVA (Analisis Varian) dan Uji BNT (Beda Nyata Terkecil). 
3. HASIL PENELITIAN DAN PEMBAHASAN

a. Hasil Determinasi Tanaman

Tanaman Pistia stratiotes L. yang digunakan dalam penelitian ini dideterminasi di laboratorium Biologi Fakultas MIPA Universitas Gajah Mada Yogyakarta. Determinasi dilakukan untuk menghindari kesalahan kekeliruan dalam pengambilan bahan penelitian. Determinasi dilakukan dengan mencocokkan keadaan morfologi tumbuhan dengan kunci-kunci determinasi dalam buku "Flora of Java". Hasil determinasi tanaman Pistia stratiotes L. adalah sebagai berikut:

$1 b-2 b-3 b-4 b-12 b-13 b-14 b-17 b-18 b-19 b-20 b-21 b-22 b-23 b-$ $24 b-25 b-26 b-27 b-799 b-800 b-801 b-802 b-803 b-804 b-805 b$. Familia: Araceae

Hasil determinasi ini menunjukkan bahwa bahan yang digunakan di dalam penelitian benar-benar tanaman Pistia stratiotes L.

b. Biological Oxygen Demand (BOD)

Nilai rata-rata BOD air limbah sebelum dan sesudah satu minggu pengolahan dan persentase penurunan nilai BOD Limbah Cair Tahu di Dusun Klero Sleman Yogyakarta dengan variasi biomassa Pistia stratiotes L. Sebagai berikut :

Tabel 1. Rerata BOD Limbah Cair Tahu di Dusun Klero Sleman Yogyakarta sebelum dan sesudah satu minggu pengolahan dengan variasi biomassa Pistia stratiotes $\mathrm{L}$.

\begin{tabular}{|c|c|c|c|c|}
\hline \multirow{2}{*}{$\begin{array}{c}\text { Biomassa } \\
\text { Kayu Apu (g) }\end{array}$} & \multicolumn{2}{|c|}{ Kadar BOD (mg/l) } & \multirow{2}{*}{$\begin{array}{c}\text { Penurunan Kadar } \\
\text { BOD (mg/l) }\end{array}$} & \multirow{2}{*}{$\begin{array}{c}\text { Persentase } \\
\text { Penurunan }(\%)\end{array}$} \\
\hline & Sebelum & Sesudah & & \\
\hline 0 & 3200,1 & 1363,43 & 1836.67 & 57,39 \\
\hline 50 & & 363,43 & 2836.67 & 88,64 \\
\hline 100 & & 406,77 & 2793.33 & 87,29 \\
\hline 150 & & 313,43 & 2886.67 & 90,20 \\
\hline 200 & & 233,43 & 2966.67 & 92,70 \\
\hline 250 & & 263,43 & 2936.67 & 91,77 \\
\hline
\end{tabular}

Keterangan:

$\begin{array}{lll}0 & =\text { Kontrol (tanpa Pistia stratiotes L.) } \\ 50 & =\text { Perlakuan Pistia stratiotes L. } 50 \mathrm{gram} \\ 100 & =\text { Perlakuan Pistia stratiotes L. } 100 \mathrm{gram} \\ 150 & =\text { Perlakuan Pistia stratiotes L. } 150 \mathrm{gram} \\ 200 & =\text { Perlakuan Pistia stratiotes L. } 200 \mathrm{gram} \\ 250 & =\text { Perlakuan Pistia stratiotes L. } 250 \mathrm{gram}\end{array}$

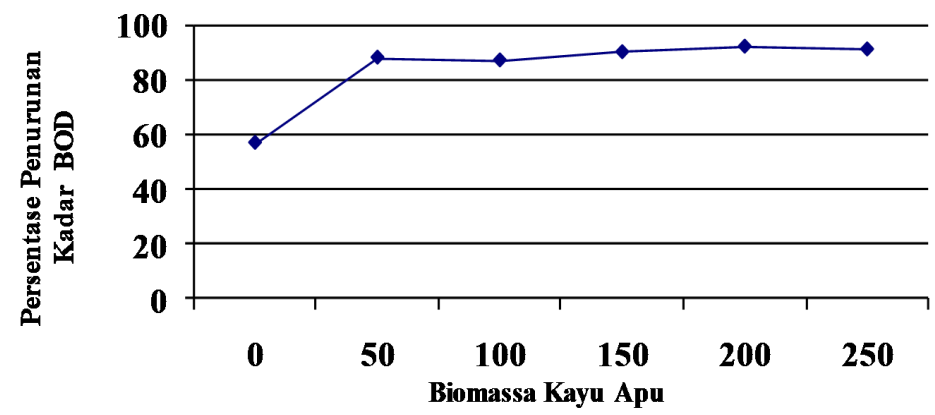

Gambar 1. Grafik persentase penurunan BOD dengan variasi biomassa Pistia stratiotes L. 
gambar 1, menunjukkan bahwa persentase penurunan nilai BOD tertinggi terletak pada biomassa kayu apu 200 gram, sedangkan persentase penurunan nilai BOD terendah terletak pada biomassa kayu apu 0 gram (kontrol).

Adapun perhitungan anova untuk Penurunan BOD Tertinggi Limbah Cair Tahu di Dusun Klero sesudah satu minggu pengolahan sebagai berikut:

Tabel 2. Hasil Penurunan BOD Tertinggi Limbah Cair Tahu di Dusun Klero sesudah satu minggu pengolahan menggunakan Uji Statistik ANOVA

\begin{tabular}{clccccc}
\hline $\begin{array}{c}\text { Biomassa } \\
\text { Kayu Apu(g) }\end{array}$ & \multicolumn{1}{c}{ SV } & JK & db & KT & F & P \\
\hline 200 & Rata-rata & 2828494.4 & 1 & 2828494.4 & 258.692 & .000 \\
\hline & Antar kelompok & 2802494.4 & 5 & 560498.889 & & \\
\cline { 3 - 6 } & Dalam kelompok & 26000.000 & 12 & 2166.667 & & \\
& & 5656988.8 & 18 & - & - & \\
\hline
\end{tabular}

Keterangan:

SV = Sumber Variansi

$\mathrm{JK}=$ Jumlah Kuadrat

$\mathrm{db}=$ Derajat Bebas

$\mathrm{KT}=$ Kuadrat Tengah

Untuk pengolahan BOD pada limbah cair tahu di Dusun Klero dengan variasi biomassa Pistia stratiotes L. mengalami penurunan. Penurunan paling besar terjadi pada biomassa 200 gram. Tetapi masih melebihi Baku Mutu Limbah Cair (BMLC) menurut SK Gubernur Kepala Daerah Yogyakarta No. 281 Tahun 1998. Setelah diuji statistik dengan uji ANOVA diketahui bahwa nilai BOD dengan variasi biomassa Pistia stratiotes L. mempunyai perbedaan yang signifikan, karena nilai signifikansi 0,000 dan $\mathrm{P}<0,05$.

Untuk perhitungan BNT diperoleh nilai $\mathrm{KT}=2166,667, \quad \mathrm{~V}=15, \quad \mathrm{r}=3$ dan $t_{0,05(15)}=2,131$

$$
\begin{aligned}
\text { LSD } & =t \frac{\sqrt{2 \mathrm{KT}}}{\mathrm{r}} \\
& =2,131 \frac{\sqrt{2.2166,667}}{3}=2,131 \times 38,005=80,98
\end{aligned}
$$

Tabel 3. Hasil Penurunan BOD Tertinggi Limbah Cair Tahu di Dusun Klero sesudah satu minggu pengolahan menggunakan Uji Beda Nyata Terkecil

\begin{tabular}{ccc}
\hline Biomassa Kayu Apu (g) & Persentase Penurunan BOD & BNT $(80,98)$ \\
\hline 0 & 57,39 & a \\
\hline 50 & 88,64 & b \\
\hline 100 & 87,29 & b \\
\hline 150 & 90,20 & $\mathrm{c}$ \\
\hline 200 & 92,70 & $\mathrm{c}$ \\
\hline 250 & 91,77 & $\mathrm{c}$ \\
\hline
\end{tabular}




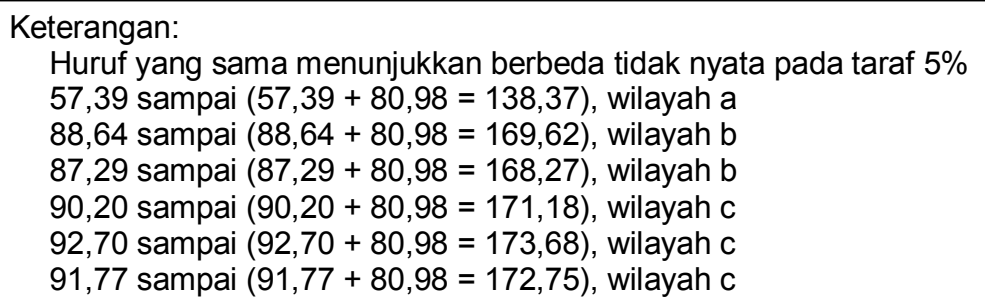

Berdasarkan hasil penelitian dan perhitungan Uji BNT, diketahui bahwa pada biomassa kayu apu 200 gram menghasilkan penurunan BOD tertinggi dibandingkan dengan perlakuan lainnya. Hal ini dapat dijelaskan bahwa penurunan kadar BOD lebih efektif pada biomassa kayu apu 200 gram dan berbeda nyata terhadap penurunan dengan biomassa kayu apu 0 gram, 50 gram, 100 gram, 150 gram, dan 250 gram.

\section{c. Chemical Oxygen Demand (COD)}

Nilai rata-rata COD air limbah sebelum dan sesudah satu minggu perlakuan dapat dilihat pada tabel 4 .

Tabel 4. Rerata COD Limbah Cair Tahu di Dusun Klero Sleman Yogyakarta sebelum dan sesudah satu minggu pengolahan dengan variasi biomassa Pistia stratiotes $\mathrm{L}$.

\begin{tabular}{|c|c|c|c|c|}
\hline \multirow{2}{*}{$\begin{array}{c}\text { Biomassa } \\
\text { Kayu Apu (g) }\end{array}$} & \multicolumn{2}{|c|}{ Kadar COD (mg/l) } & \multirow{2}{*}{$\begin{array}{c}\text { Penurunan } \\
\text { Kadar COD (mg/l) }\end{array}$} & \multirow{2}{*}{$\begin{array}{c}\text { Persentase } \\
\text { Penurunan (\%) }\end{array}$} \\
\hline & Sebelum & Sesudah & & \\
\hline 0 & 9200 & 2546,67 & 6653.33 & 72,32 \\
\hline 50 & & 363,43 & 8836.57 & 96,05 \\
\hline 100 & & 1280 & 7920 & 86,08 \\
\hline 150 & & 1046,67 & 8153.33 & 88,62 \\
\hline 200 & & 866,67 & 8333.33 & 90,58 \\
\hline 250 & & 926,67 & 8273.33 & 89,93 \\
\hline
\end{tabular}

Keterangan:

$0=$ Kontrol (tanpa Pistia stratiotes L.)

50 = Perlakuan Pistia stratiotes L. 50 gram

100 = Perlakuan Pistia stratiotes L. 100 gram

$150=$ Perlakuan Pistia stratiotes L. 150 gram

$200=$ Perlakuan Pistia stratiotes L. 200 gram

$250=$ Perlakuan Pistia stratiotes L. 250 gram

Untuk lebih jelasnya, persentase penurunan nilai COD Limbah Cair Tahu di Dusun Klero Sleman Yogyakarta dengan variasi biomassa Pistia stratiotes L. tertera pada Gambar 2.

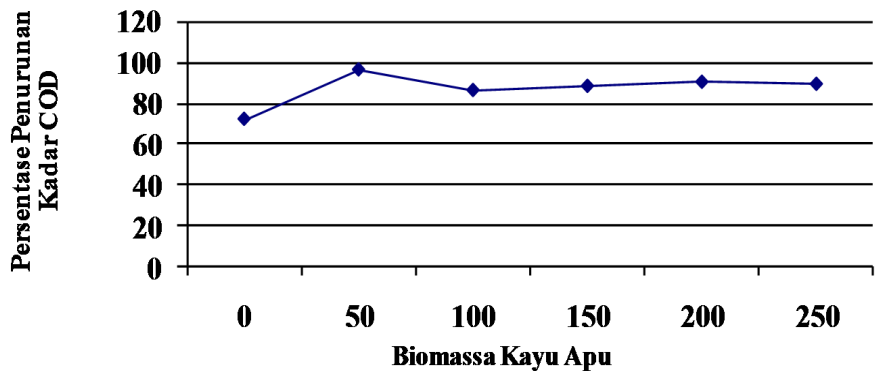

Gambar 2. Grafik persentase penurunan COD dengan variasi biomassa Pistia stratiotes L. 
gambar 2, menunjukkan bahwa persentase penurunan nilai COD tertinggi terletak pada biomassa kayu apu 50 gram, sedangkan persentase penurunan nilai COD terendah terletak pada biomassa kayu apu 0 gram (kontrol).

Adapun perhitungan anava untuk Penurunan COD Tertinggi Limbah Cair Tahu di Dusun Klero sesudah satu minggu pengolahan dapat dilihat pada tabel 5 sebagai berikut:

Tabel 5. Hasil Penurunan COD Tertinggi Limbah Cair Tahu di Dusun Klero sesudah satu minggu pengolahan menggunakan Uji Statistik ANOVA

\begin{tabular}{|c|c|c|c|c|c|c|}
\hline $\begin{array}{c}\text { Biomassa } \\
\text { Kayu Apu (g) }\end{array}$ & SV & JK & $\mathrm{db}$ & $\mathrm{KT}$ & $\mathrm{F}$ & $\mathrm{P}$ \\
\hline 50 & Rata-rata & 6079161.1 & 1 & 6079161.1 & 49.399 & .000 \\
\hline & Antar kelompok & 5797494.4 & 5 & 1159498.889 & & \\
\hline $\mathrm{r}_{0}$ & Dalam kelompok & 281666.67 & 12 & 23472.222 & & \\
\hline Total & & 12158321 & 18 & - & - & - \\
\hline $\begin{array}{l}\text { Keterangan: } \\
\text { SV } \\
\text { JK } \\
\text { db } \\
\text { KT }\end{array}$ & $\begin{array}{l}=\text { Sumber Variansi } \\
=\text { Jumlah Kuadrat } \\
=\text { Derajat Bebas } \\
=\text { Kuadrat Tengah }\end{array}$ & & & & & \\
\hline
\end{tabular}

Untuk pengolahan COD pada limbah cair tahu di Dusun Klero dengan variasi biomassa Pistia stratiotes L. mengalami penurunan. Penurunan paling besar terjadi pada biomassa 50 gram. Tetapi masih melebihi Baku Mutu Limbah Cair (BMLC) menurut SK Gubernur Kepala Daerah Yogyakarta No. 281 Tahun 1998. Setelah diuji ANOVA diketahui bahwa nilai COD dengan variasi biomassa Pistia stratiotes L. mempunyai perbedaan yang signifikan, karena nilai signifikansi 0,000 dan $P<0,05$.

Untuk perhitungan BNT diperoleh nilai $\mathrm{KT}=23472,222, \quad \mathrm{~V}=15, \quad \mathrm{r}=3$ dan $\mathrm{t}_{0,05(15)}=2,131$

$$
\begin{aligned}
\text { LSD } & =\mathrm{t} \\
& =2,131 \frac{\sqrt{2 \mathrm{KT}}}{\mathrm{r}} \\
\frac{\sqrt{2.23472,222}}{3} & =2,131 \times 125,09=266.56
\end{aligned}
$$

Tabel 6. Hasil Penurunan COD Tertinggi Limbah Cair Tahu di Dusun Klero sesudah satu minggu pengolahan menggunakan Uji Beda Nyata Terkecil

\begin{tabular}{ccc}
\hline $\begin{array}{c}\text { Biomassa } \\
\text { Kayu Apu (g) }\end{array}$ & $\begin{array}{c}\text { Persentase } \\
\text { Penurunan COD }\end{array}$ & $\begin{array}{c}\text { BNT } \\
(266,56)\end{array}$ \\
\hline 0 & 72,32 & $\mathrm{a}$ \\
\hline 50 & 96,05 & $\mathrm{~b}$ \\
\hline 100 & 86,08 & $\mathrm{c}$ \\
\hline 150 & 88,62 & $\mathrm{c}$ \\
\hline 200 & 90,58 & $\mathrm{c}$ \\
\hline 250 & 89,93 & $\mathrm{c}$ \\
\hline
\end{tabular}




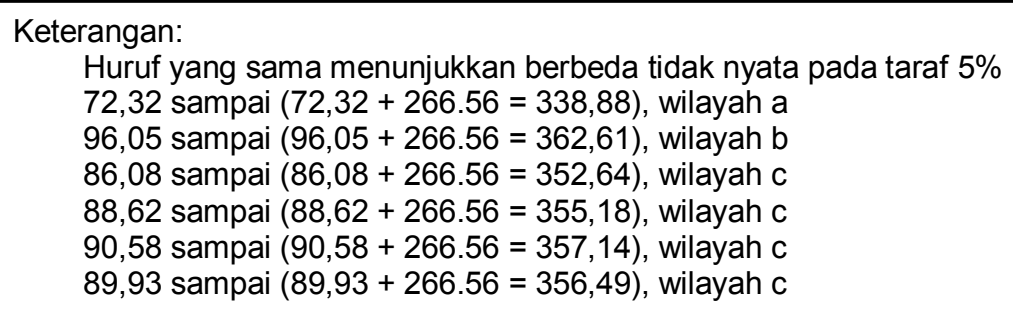

Berdasarkan hasil penelitian dan perhitungan Uji BNT, diketahui bahwa pada biomassa kayu apu 50 gram menghasilkan penurunan COD tertinggi dibandingkan dengan perlakuan lainnya. Hal ini dapat dijelaskan bahwa penurunan kadar COD lebih efektif pada biomassa kayu apu 50 gram dan berbeda nyata terhadap penurunan dengan biomassa kayu apu 0 gram, 100 gram, 150 gram, 200 gram, dan 250 gram.

\section{d. Total Suspended Solid (TSS)}

Nilai rata-rata TSS air limbah sebelum dan sesudah satu minggu pengolahan dapat dilihat pada tabel 7 .

Tabel 7. Rerata TSS Limbah Cair Tahu di Dusun Klero Sleman Yogyakarta sebelum dan sesudah satu minggu pengolahan dengan variasi biomassa Pistia stratiotes $\mathrm{L}$.

\begin{tabular}{ccccc}
\hline \multirow{2}{*}{$\begin{array}{c}\text { Biomassa } \\
\text { Kayu Apu(g) }\end{array}$} & \multicolumn{2}{c}{ Kadar TSS (mg/l) } & $\begin{array}{c}\text { Penurunan Kadar } \\
\text { TSS (mg/l) }\end{array}$ & $\begin{array}{c}\text { Persentase } \\
\text { Penurunan (\%) }\end{array}$ \\
\cline { 2 - 3 } Sebelum & Sesudah & & \\
\hline 0 & 1580 & 745 & 835 & 52,85 \\
\hline 50 & & 336,33 & 1243.67 & 78,71 \\
\hline 100 & 403,33 & 1176.67 & 74,47 \\
\hline 150 & 338 & 1242 & 78,61 \\
\hline 200 & 341,33 & 1238.67 & 78,39 \\
\hline 250 & 242,67 & 1337.33 & 84,64 \\
\hline
\end{tabular}

Keterangan:
$0 \quad=$ Kontrol (tanpa Pistia stratiotes L.)
$50 \quad=$ Perlakuan Pistia stratiotes L. 50 gram
$100=$ Perlakuan Pistia stratiotes L. 100 gram
$150=$ Perlakuan Pistia stratiotes L. 150 gram
$200=$ Perlakuan Pistia stratiotes L. 200 gram
$250=$ Perlakuan Pistia stratiotes L. 250 gram

Untuk lebih jelasnya, persentase penurunan nilai TSS Limbah Cair Tahu di Dusun Klero Sleman Yogyakarta dengan variasi biomassa Pistia stratiotes L. tertera pada Gambar 3.

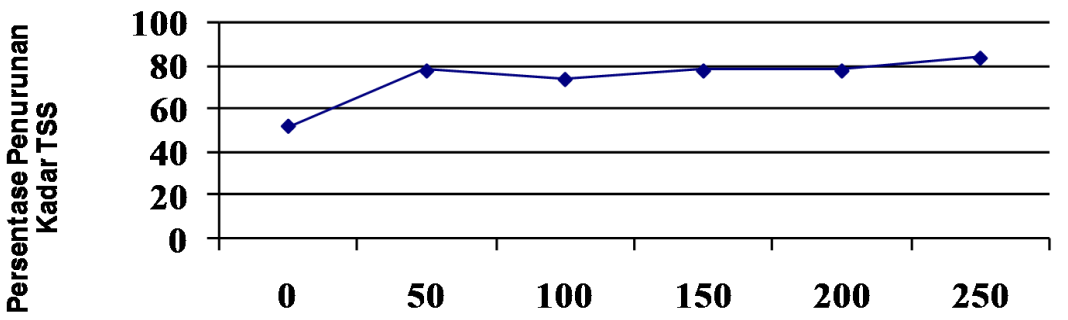

Biomassa Kayu Apu

Gambar 3. Grafik persentase penurunan TSS dengan variasi biomassa Pistia stratiotes L. 
Gambar 3, menunjukkan bahwa persentase penurunan nilai TSS tertinggi terletak pada biomassa kayu apu 250 gram, sedangkan persentase penurunan nilai TSS terendah terletak pada biomassa kayu apu 0 gram (kontrol).

Adapun perhitungan anava untuk Penurunan TSS Tertinggi Limbah Cair Tahu di Dusun Klero sesudah satu minggu pengolahan dapat dilihat pada tabel 10 sebagai berikut:

Tabel 8. Hasil Penurunan TSS Tertinggi Limbah Cair Tahu di Dusun Klero sesudah satu minggu pengolahan menggunakan Uji Statistik ANOVA

\begin{tabular}{|c|c|c|c|c|c|c|}
\hline $\begin{array}{c}\text { Biomassa } \\
\text { Kayu Apu(g) }\end{array}$ & SV & JK & $\mathrm{db}$ & KT & $\mathrm{F}$ & $P$ \\
\hline 250 & Rata-rata & 546533.78 & 1 & 546533.78 & 13.760 & .000 \\
\hline & Antar kelompok & 465365.11 & 5 & 93073.022 & & \\
\hline & Dalam kelompok & 81168.667 & 12 & 6764.056 & & \\
\hline$\checkmark$ Total & & 1093067.5 & 18 & - & - & \\
\hline
\end{tabular}

Keterangan:

SV = Sumber Variansi

$\mathrm{JK}=$ Jumlah Kuadrat

$\mathrm{db}=$ Derajat Bebas

$\mathrm{KT}=$ Kuadrat Tengah

Untuk pengolahan TSS pada limbah cair tahu di Dusun Klero dengan variasi biomassa Pistia stratiotes L. mengalami penurunan. Penurunan paling besar terjadi pada biomassa 250 gram. Tetapi masih melebihi Baku Mutu Limbah Cair (BMLC) menurut SK Gubernur Kepala Daerah Yogyakarta No. 281 Tahun 1998. Setelah diuji statistik dengan uji ANOVA diketahui bahwa nilai TSS dengan variasi biomassa Pistia stratiotes L. mempunyai perbedaan yang signifikan, karena nilai signifikansi 0,000 dan $\mathrm{P}<0,05$.

Untuk perhitungan BNT diperoleh nilai KT $=6764,056, \quad \mathrm{~V}=15, \quad \mathrm{r}=3$ dan $\mathrm{t}_{0,05(15)}=2,131$

$$
\begin{aligned}
\text { LSD } & =\mathrm{t} \frac{\sqrt{2 \mathrm{KT}}}{\mathrm{r}} \\
& =2,131 \frac{\sqrt{2.6764,056}}{3}=2,131 \times 67,15=143.09
\end{aligned}
$$

Tabel 9. Hasil Penurunan TSS Tertinggi Limbah Cair Tahu di Dusun Klero sesudah satu minggu pengolahan menggunakan Uji Beda Nyata Terkecil

\begin{tabular}{ccc}
\hline $\begin{array}{c}\text { Biomassa } \\
\text { Kayu Apu(g) }\end{array}$ & $\begin{array}{c}\text { Persentase } \\
\text { Penurunan TSS }\end{array}$ & $\begin{array}{c}\text { BNT } \\
(143,09)\end{array}$ \\
\hline 0 & 52,85 & $\mathrm{a}$ \\
\hline 50 & 78,71 & $\mathrm{~b}$ \\
\hline 100 & 74,47 & $\mathrm{c}$ \\
\hline 150 & 78,61 & $\mathrm{~b}$ \\
\hline 200 & 78,39 & $\mathrm{~b}$ \\
\hline 250 & 84,64 & $\mathrm{~b}$ \\
\hline
\end{tabular}


Keterangan:

Huruf yang sama menunjukkan berbeda tidak nyata pada taraf $5 \%$

52,85 sampai $(52,85+143.09=195,94)$, wilayah a

78,71 sampai $(78,71+143.09=221,8)$, wilayah $b$

74,47 sampai $(74,47+143.09=217,56)$, wilayah c

78,61 sampai $(78,61+143.09=221,7)$, wilayah $b$

78,39 sampai $(78,39+143.09=221,48)$, wilayah b

84,64 sampai $(84,64+143.09=227,73)$, wilayah $b$

Berdasarkan hasil penelitian dan perhitungan Uji BNT, diketahui bahwa pada biomassa kayu apu 250 gram menghasilkan penurunan TSS tertinggi dibandingkan dengan perlakuan lainnya. Hal ini dapat dijelaskan bahwa penurunan kadar TSS lebih efektif pada biomassa kayu apu 250 gram dan berbeda nyata terhadap penurunan dengan biomassa kayu apu 0 gram, 50 gram, 100 gram, 150 gram, dan 200 gram.

\section{e. Hasil Perubahan Morfologi Pistia stratiotes L.}

Perubahan morfologi Pistia stratiotes L. setelah dipergunakan untuk pengolahan limbah cair tahu di Dusun Klero dapat dilihat dalam gambar di bawah ini:

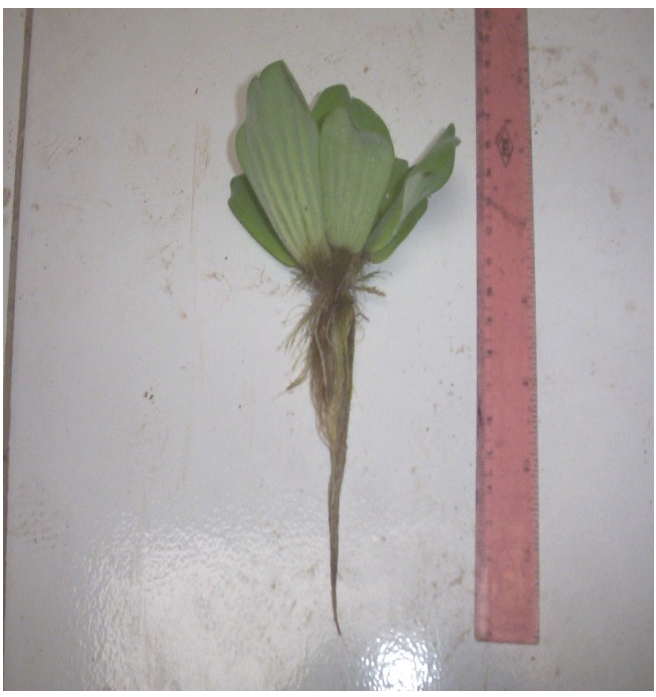

Gambar 4. Pistia stratiotes L. Sebelum Penelitian (tampak akar bersih dan tidak saling melekat)

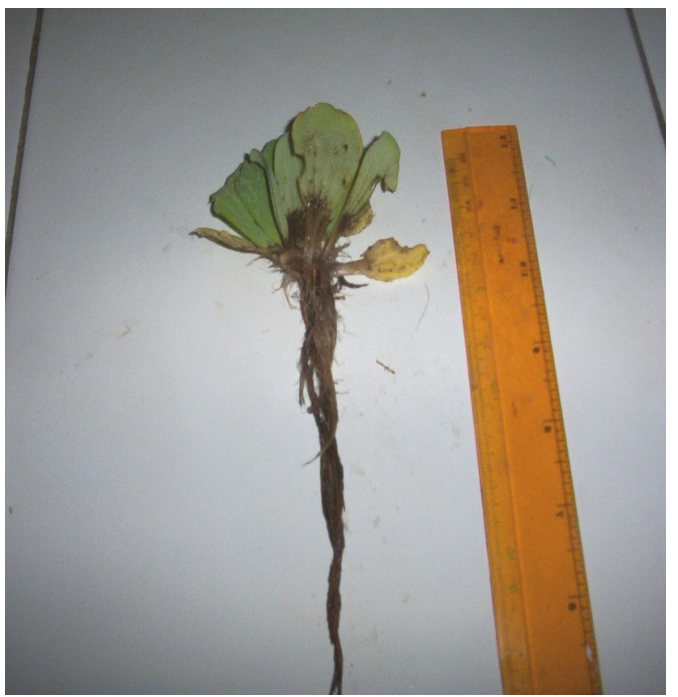

Gambar 5. Pistia stratiotes L. Setelah Penelitian (tampak akar saling melekat karena adanya koloid yang menempel)

\section{f. Pembahasan}

1) Pengaruh Variasi Biomassa Pistia stratiotes L. Terhadap Penurunan Kadar Biological Oxygen Demand (BOD)

Nilai BOD menunjukkan banyaknya jumlah oksigen terlarut yang digunakan oleh mikrobia untuk mendegradasi bahan organik di dalam air ${ }^{17}$.

Berdasarkan gambar 1, pemberian Pistia stratiotes L. 200 gram menunjukkan penurunan BOD yang paling tinggi dibandingkan perlakuan lainnya. Hal ini dapat dijelaskan bahwa Pistia 200 gram memberikan suplai oksigen yang terbaik. Selanjutnya Pistia stratiotes L. 250 gram juga mengalami penurunan pada persentase turunnya BOD. Keadaan ini dapat dijelaskan 
bahwa biomassa Pistia stratiotes L. yang sangat banyak maka suplai oksigen tinggi. Selain itu, hasil fotosintesis yang dilakukan oleh tanaman juga dapat mensuplai kebutuhan akan oksigen yang akan digunakan untuk menguraikan bahan organik yang terdapat di dalam air limbah. Hal ini ditunjukkan dengan penurunan BOD yang semakin rendah.

Selama penelitian, persentase penurunan kadar BOD tertinggi terjadi pada biomassa Pistia stratiotes L. 200 gram yaitu sebesar $2966.67 \mathrm{mg} / \mathrm{l}$ $(92,70 \%)$. Penurunan BOD ini disebabkan oleh menurunnya kandungan bahan organik dalam air limbah. Selain itu, penurunan ini juga disebabkan karena tanaman Pistia stratiotes L. juga mensuplai oksigen ke dalam limbah dan menyerap hasil dekomposisi bahan organik.

Sesuai dengan definisi BOD maka limbah itu semakin buruk apabila BOD semakin tinggi. Sehingga BOD dapat dipergunakan untuk menentukan kepekatan limbah atau baik buruknya limbah. Limbah yang mempunyai BOD tinggi pada dasarnya tidak selalu lebih buruk daripada limbah yang mempunyai BOD rendah. BOD itu dapat digunakan sebagai ukuran kualitas limbah cair atau air apabila tidak ada gangguan terhadap aktivitas mikroorganisme ${ }^{18}$.

Pada umumnya, besarnya nilai BOD dipengaruhi oleh kecepatan aktivitas mikroorganisme dalam mendekomposisi bahan organik, jumlah dan keadaan mikroorganisme serta suplai oksigen terlarut baik dari udara dan fotosintesis tanaman. Jumlah mikroorganisme aerobik dipengaruhi oleh bahan organik yang tersedia, difusi dari udara dan senyawa-senyawa yang bersifat toksik. Banyaknya bahan organik yang tersedia dalam air limbah akan meningkatkan pertumbuhan mikroorganisme ${ }^{3}$. Apabila banyak senyawa toksik dalam air limbah akan menurunkan jumlah mikroorganisme. Keberadaan mikroorganisme dalam air limbah berfluktuasi dan akan mempengaruhi juga terhadap jumlah oksigen yang dibutuhkan oleh mikroorganisme aerobik. Nilai BOD yang tertinggi ditunjukkan dari tingginya bahan organik yang didegradasi secara biologis ${ }^{10}$.

Nilai BOD dipengaruhi juga oleh adanya tanaman yang menutupi permukaan air limbah. Keberadaan tanaman tersebut dapat menyerap zat organik yang terdapat dalam air limbah. Semakin banyak tanaman, maka semakin banyak bahan organik yang terserap dan bahan organik yang harus didegradasi oleh mikroorganisme semakin sedikit. Semakin sedikit bahan organik yang harus didegradasi oleh mikrobia, maka kandungan oksigen dalam air limbah semakin tinggi. Oksigen terlarut dalam air limbah juga semakin banyak karena adanya suplai oksigen dari hasil fotosintesis tanaman. Jadi semakin banyak tanaman, maka nilai BOD semakin kecil yang berarti semakin baik kualitas air limbah tersebut.

2) Pengaruh Variasi Biomassa Pistia stratiotes L. Terhadap Penurunan Kadar Chemical Oxygen Demand (COD)

COD Merupakan jumlah oksigen yang dibutuhkan untuk mengoksidasi bahan organik dalam air secara kimiawi ${ }^{3}$. Jika bahan organik yang belum diolah dibuang ke badan perairan, maka bakteri akan menggunakan oksigen untuk proses pembusukannya. Nilai COD biasanya lebih tinggi dari pada nilai BOD karena bahan buangan yang dapat dioksidasi melalui proses kimia lebih banyak dari pada bahan buangan yang dapat dioksidasi melalui proses bioligi ${ }^{12}$.

Berdasarkan gambar 2, pemberian Pistia stratiotes L. 50 gram menunjukkan penurunan COD yang paling tinggi dibandingkan perlakuan lainnya. Hal ini dapat dijelaskan bahwa Pistia 50 gram memberikan suplai oksigen yang terbaik. Selanjutnya Pistia stratiotes L. 250 gram juga mengalami penurunan pada persentase turunnya COD. Keadaan ini dapat dijelaskan 
bahwa biomassa Pistia stratiotes L. yang sangat banyak maka suplai oksigen tinggi. Selain itu, hasil fotosintesis yang dilakukan oleh tanaman juga dapat mensuplai kebutuhan akan oksigen yang akan digunakan untuk menguraikan bahan organik yang terdapat di dalam air limbah. Hal ini ditunjukkan dengan penurunan COD yang semakin rendah.

Selama satu minggu pengolahan, penurunan kadar COD yang tertinggi terjadi pada biomassa Pistia stratiotes L. 50 gram yaitu sebesar $8836.57 \mathrm{mg} / \mathrm{l}$ $(96,05 \%)$. Penurunan nilai COD tersebut disebabkan karena bahan padatan telah mulai mengendap sehingga bahan buangan di air limbah juga berkurang. Selain itu, sebagian bahan buangan telah teroksidasi dan sebagian lagi juga telah terserap oleh tanaman sehingga juga mengurangi nilai COD. Penurunan ini juga dikarenakan suplai oksigen terlarut cukup banyak terutama dari hasil fotosintesis tanaman sehingga menyebabkan dekomposisi bahan organik menjadi lebih efektif.

Pada perlakuan kontrol (tanpa pemberian Pistia stratiotes L.), penurunan kadar COD paling rendah yaitu sebesar $6653.33 \mathrm{mg} / \mathrm{l}(72,32 \%)$. Hal ini disebabkan karena oksigen terlarut yang digunakan untuk mendekomposisi bahan organik dalam air limbah tersedia dalam jumlah yang sedikit dan hanya mendapat suplai dari udara atau lingkungan luar saja. Untuk penurunan kadar COD pada biomassa Pistia stratiotes L. 250 gram lebih kecil dari penurunan kadar COD pada biomassa Pistia stratiotes L. 200 gram. Hal ini disebabkan karena untuk biomassa 250 gram terdapat banyak tanaman yang rusak. Daundaun yang telah rusak dan terendam air limbah akan membusuk. Pembusukan tersebut tentu akan menambah jumlah bahan organik dalam air limbah sehingga oksigen yang terlarut menjadi berkurang dan akhirnya menambah nilai COD air limbah.

Selain dipengaruhi oleh banyaknya bahan buangan dan oksigen terlarut, nilai COD juga dipengaruhi oleh keberadaan tanaman dalam air limbah. Tanaman tentu melakukan proses fotosintesis dan menghasilkan oksigen sehingga mensuplai kebutuhan akan oksigen yang akan digunakan untuk menguraikan bahan organik yang terdapat di dalam air limbah. Keberadaan tanaman dapat menurunkan nilai COD yaitu dengan diserapnya bahan-bahan organik oleh tanaman. Keberadaan tanaman juga dapat menaikkan nilai COD yaitu daun-daun yang telah rusak akan membusuk karena terendam oleh air sehingga bahan organik dalam air limbah akan meningkat dan nilai COD akan naik.

3) Pengaruh Variasi Biomassa Pistia stratiotes L. Terhadap Penurunan Kadar Total Suspended Solid (TSS)

Nilai padatan tersuspensi total menunjukkan banyaknya bahan yang tersuspensi di dalam air. Menurut ${ }^{12}$. TSS (Total Suspended Solid) adalah berat $\mathrm{mg} / \mathrm{l}$ kering lumpur yang ada dalam air limbah setelah mengalami penyaringan dengan membran berukuran 0,45 mikron. Analisa TSS atau padatan tersuspensi penting dilakukan untuk mengetahui kuantitas senyawa-senyawa organik dan anorganik yang larut dalam air, mineral, dan garam. Dalam aplikasi, penurunan nilai TSS digunakan sebagai dasar pengolahan dan pengawasan air minum atau air buangan.

Berdasarkan gambar 3, pemberian Pistia stratiotes L. 250 gram menunjukkan penurunan TSS yang paling tinggi dibandingkan perlakuan lainnya. Hal ini dapat dijelaskan bahwa Pistia 250 gram mampu menyerap atau menyaring material tersuspensi paling banyak dibandingkan pada perlakuan lainnya. Keadaan ini dapat dijelaskan bahwa biomassa Pistia stratiotes L. yang sangat banyak dapat menurunkan kadar TSS pada air limbah. 
Selama satu minggu pengolahan, penurunan TSS yang tertinggi terjadi pada biomassa Pistia stratiotes L. 250 gram sedangkan penurunan nilai terendah terjadi pada kontrol (tanpa pemberian Pistia stratiotes L.). Pada kontrol, penurunan nilai TSS semata-mata hanya disebabkan adanya gaya gravitasi pengendapan saja. Untuk penurunan nilai TSS pada perlakuan biomassa Pistia stratiotes L. disebabkan karena terjadi proses penyerapan oleh tanaman, dekomposisi bahan organik terlarut dan mengendapnya hasil dekomposisi bahan organik. Penurunan nilai TSS juga disebabkan karena tanaman Pistia stratiotes L. memiliki akar serabut yang dapat menjadi tempat menempelnya koloid yang melayang di air. Semakin tinggi biomassa tanaman, semakin banyak akar serabutnya, maka semakin banyak koloid yang menempel di akar-akar tersebut.

Endapan dan koloid serta bahan terlarut yang berasal dari bahan buangan yang berbentuk padat akan mengendap di dasar bila tidak dapat larut dan sebagian akan menjadi koloidal bila dapat larut. Endapan yang tidak dapat larut sebelum mencapai dasar akan melayang-layang di dalam air bersama koloidal. Bahan buangan organik yang berupa koloid akan menggumpal di permukaan air sehingga air akan tampak keruh. Penggumpalam koloid tersebut akan menghambat difusi oksigen ke air limbah sehingga ketersediaan oksigen menjadi sedikit dan akan menghambat kerja mikroorganisme aerobik dalam mendekomposisi bahan organik.

Material tersuspensi mempunyai efek yang kurang baik terhadap kualitas badan air karena dapat menyebabkan menurunkan kejernihan air dan dapat mempengaruhi kemampuan ikan untuk melihat dan menangkap makanan serta menghalangi sinar matahari masuk ke dalam air. Endapan tersuspensi dapat juga menyumbat insang ikan, mencegah telur berkembang. Ketika suspended solid tenang di dasar badan air, dapat menyembunyikan telur dan terjadi pendangkalan pada badan air sehingga memerlukan pengerukan yang memerlukan biaya operasional tinggi ${ }^{19}$.

TSS berhubungan erat dengan kekeruhan air. Semakin tinggi nilai TSS, air akan semakin keruh. Hal ini dapat mengakibatkan terhalangnya sinar matahari yang akan masuk ke dalam air, sehingga fotosintesis akan terganggu dan berdampak pada turunnya kadar oksigen terlarut. Kadar oksigen terlarut yang turun akan banyak mengganggu aktivitas kehidupan makhluk hidup dalam air.

4) Kondisi Morfologi Pistia stratiotes L. setelah pengolahan terhadap limbah cair tahu di Dusun Klero selama satu minggu

Pada kondisi morfologi tanaman Pistia stratiotes L. setelah dipergunakan sebagai sarana pengolahan limbah cair tahu di Dusun Klero selama satu minggu, keadaan tanaman sebagian masih hidup tetapi ada juga yang sudah rusak dan membusuk di dasar ember penelitian. Sebelum dipergunakan untuk pengolahan limbah, daunnya berwarna hijau segar sedangkan setelah dipergunakan daunnya menjadi berwarna kekuningan. Pada biomassa Pistia stratiotes L. 250 gram, tanaman tersebut cepat menguning. Hal ini disebabkan ruang kosong untuk berkembang dalam ember sudah tidak ada sehingga kemampuan tanaman tersebut bertahan hidup menjadi berkurang dan akhirnya cepat menguning. Untuk biomassa $150 \mathrm{gram}$, tanamannya lebih cepat menutupi seluruh permukaan ember dibanding dengan biomassa yang lain. Setelah dipergunakan untuk pengolahan, akarnya bertambah panjang dan semakin banyak jumlahnya. Selain itu, akarnya juga menjadi lebih kotor dibanding sebelum dipergunakan untuk pengolahan. Hal tersebut dikarenakan banyaknya koloid dalam air limbah yang menempel di akar tanaman. 
Gambar 4, dapat dilihat perubahan morfologi tanaman Pistia stratiotes L. antara lain adalah:

a) Perubahan pada daun: beban polutan tinggi akan menurunkan kualitas dan kuantitas klorofil, sehingga menyebabkan daun berubah warna.

b) Perubahan pada akar: TSS akan berpengaruh pada respirasi sel di akar, yaitu untuk masuknya oksigen ke jaringan akar. Akar terganggu, disebabkan karena penyaringan atau filter yang dilakukan oleh akar pada air limbah.

\section{SIMPULAN DAN SARAN}

\section{a. Simpulan}

Terdapat pengaruh variasi biomassa Pistia stratiotes L. terhadap penurunan kadar BOD, COD, dan TSS limbah cair tahu di Dusun Klero Sleman Yogyakarta.

1) Biomassa Pistia stratiotes L. yang dibutuhkan untuk menurunkan kadar BOD, COD, dan TSS limbah cair tahu di Dusun Klero Sleman Yogyakarta berturutturut adalah 200 gram, 50 gram, dan 250 gram.

2) Persentase penurunan paling besar kadar BOD, COD, dan TSS limbah cair tahu di Dusun Klero Sleman Yogyakarta dengan variasi biomassa Pistia stratiotes L. terdapat pada biomassa Pistia stratiotes L. 200 gram, 50 gram, dan 250 gram.

3) Terdapat perbedaan rerata jumlah penurunan kadar BOD, COD, dan TSS limbah cair tahu di Dusun Klero Sleman Yogyakarta sebelum dan sesudah 1 minggu pengolahan dengan variasi biomassa Pistia stratiotes $\mathrm{L}$.

\section{b. Saran}

1) Industri tahu di Dusun Klero:

Memanfaatkan tanaman Pistia stratiotes L. sebagai biofilter limbah cair tahu.

2) Dinas kesehatan atau Instansi terkait :

Perlu dilakukan pemberian informasi tentang manfaat Pistia stratiotes L. sebagai pengolah limbah yang murah dan aman serta ramah lingkungan melalui penyuluhan maupun program pemberdayaan masyarakat.

3) Peneliti Lain :

a) Perlu dicari jenis tanaman lain, contohnya Hydrilla verticillata, Spirogyra $s p$ yang dapat menurunkan kadar pencemar.

b) Untuk penelitian selanjutnya, sebaiknya diusahakan memanfaatkan tanaman yang mempunyai daya tahan terhadap limbahnya baik, variasi biomassa diperbesar, sehingga dapat menggunakan konsentrasi limbah yang lebih tinggi lagi dan pengaruh variasi biomassa akan dapat terlihat.

\section{DAFTAR PUSTAKA}

1. AAK, Kedelai, Kanisius, Yogyakarta.1991

2. EMDI dan BAPEDAL, Limbah Cair Berbagai Industri Di Indonesia: Sumber, Pengendalian dan Baku Mutu, Project of the Ministry for the Environment, Republic of Indonesia and Dalhousie University, Canada.1994

3. Wardhana, W.A., Dampak Pencemaran Lingkungan (Edisi Revisi), Andi Offset, Yogyakarta.2001 
4. Haslam, S. M., River Pollution, an Ecological Perspective, Belhaven Press, London.1997

5. Tjitrosoepomo, G., 1981, Penelitian Gulma Air, Waduk Sempor (Daerah Saluran Induk Sempor Timur). Direktorat Jenderal Perairan Pembangunan Kedu Selatan, Departemen Pekerjaan Umum, Gembong.

6. Satriago, H., 1996, Himpunan Istilah Lingkungan Untuk Manajemen, Gramedia Pustaka Utama, Jakarta.

7. Mukono, 2000, Prinsip Dasar Kesehatan Lingkungan, Airlangga University Press, Surabaya.

8. Nurhasan dan Pramudyanto, 1991, Penanganan Limbah Pabrik Tahu, Bintari, Semarang.

9. Sugiharto, 1987, Dasar-dasar Pengolahan Limbah, Universitas Indonesia, Jakarta.

10. Hammer, M.J., 1997, Water and Waste-Water Technology, John Willey and Sons, New York.

11. Ginting,P., 1992, Mencegah dan Mengendalikan Pencemaran Industri, Pustaka sinar Harapan, Jakarta.

12. Fardiaz, 2000, Polusi Air dan Udara, Edisi Ke-7., Kanisius, Yogyakarta.

13. Sutrisno T.C dan Suciastuti, 1996, Teknologi Penyediaan Air Bersih, PT. Rineka Cipta, Jakarta.

14. Damayanti, A., 2003, Pengelolaan Limbah Tahu Dengan Menggunakan Kayu Apu ( Pistia stratiotes L.), Tesis, Institut Teknologi Surabaya.

15. Cook C.D.K., 1996, Aquatic and Wetland Plants of India, Oxford University Press, Oxford.

16. Rahmatullah, L. 2008. Penggunaan Tanaman Kiapu (Pistia stratiotes L.) Sebagai Pengolahan Pendahuluan Untuk Air Permukaan Dengan Parameter Warna dan TDS "Studi Kasus Air Selokan Mataram", Skripsi, FTSP, UII Yogyakarta.

17. Kristanto, P., 2002, Ekologi Industri, Andi Offset, Yogyakarta.

18. Darmono, 2001, Lingkungan Hidup dan Pencemaran, UI Press, Jakarta.

19. Puspita, D. 2008. Penurunan Konsentrasi Total Suspended Solid (TSS) pada Limbah Laundry Menggunakan Reaktor Biosand Filter Disertai Reaktor Aktivated Carbon, Skripsi, FTSP, UII Yogyakarta. 


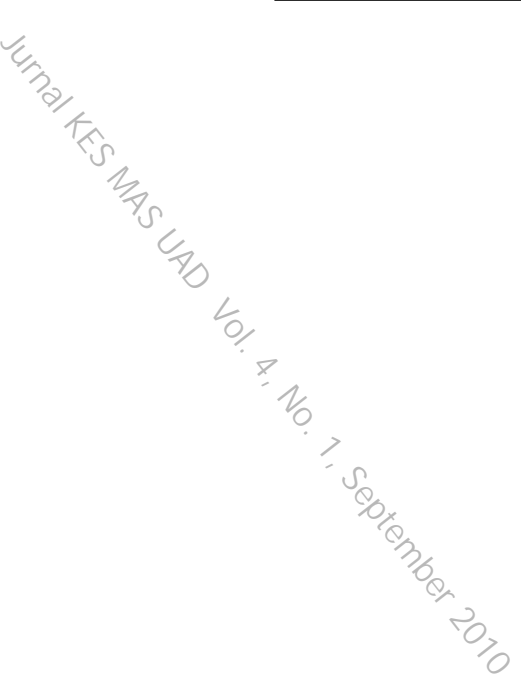

KES MAS Vol. 4, No. 1, Januari 2010: 1 - 75 